\title{
Abiotic and biotic data of the rivers Pinka and Lafnitz 2012 - 2014
}

Heidelinde Trimmel (D), Gerda Kalny, Florian Dossi, Herbert Formayer , Wolfram Graf, Patrick Leitner, David Leidinger, Imran Nadeem, Hans Peter Rauch, Philipp Weihs \& Andreas Melcher
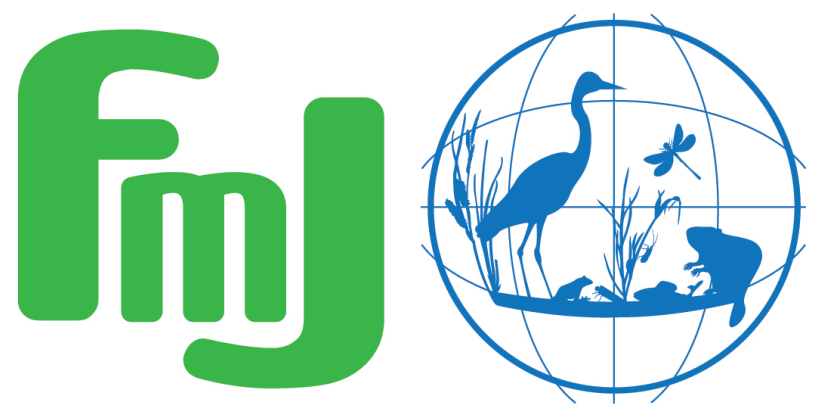

Freshwater Metadata Journal 



\section{Abiotic and biotic data of the rivers Pinka and Lafnitz 2012 - 2014}

Heidelinde Trimmel ${ }^{1}$ (iD , Gerda Kalny ${ }^{2}$, Florian Dossi ${ }^{3}$, Herbert Formayer $^{1}$, Wolfram Graf ${ }^{3}$ , Patrick Leitner ${ }^{3}$, David Leidinger ${ }^{1}$, Imran Nadeem ${ }^{1}$, Hans Peter Rauch ${ }^{2}$, Philipp Weihs ${ }^{1}$ \& Andreas Melcher ${ }^{3}$

1 Institute of Meteorology, University of Natural Resources and Life Sciences, Vienna, Austria

2 Institute of Soil Bioengineering and Landscape Construction, Univ. of Nat. Res., Vienna, Austria

3 Institute of Hydrobiology and Aquatic Ecosystem Management, Univ. of Nat. Res., Vienna, Austria

Please cite this paper as follows: Trimmel, H., Kalny, G., Dossi, F., Formayer, H., Graf, W., Leitner, P., Leidinger, D., Nadeem, I., Rauch, H. P. , Weihs, P. \& Melcher, A., 2017. Abiotic and biotic data of the rivers Pinka and Lafnitz 2012 - 2014. Freshwater Metadata Journal 22: 1-12.

https://doi.org/10.15504/fmj.2017.22

Received: 2016-07-01 / Published: 2017-03-08

\section{Keywords}

stream temperature, riparian vegetation, Pinka, Lafnitz, simulations, benthic invertebrates, fish, climate change, Heat Source, oberservations

\section{Short description of the dataset/summary}

During the project BIO_CLIC abiotic and biotic data of the rivers Pinka and Lafnitz were collected from the year 2012 until 2014, in order to analyse the present state of river morphology, riparian vegetation, riparian microclimate, fish species and benthic invertebrate abundance and diversity. This data was produced to be able to predict the near stream microclimate and stream water temperature until the end of the century, estimate the stress on aquatic organisms and the ability of vegetation to mitigate this stress.

Initially only stream water observations, predictions of the river Pinka and corresponding input data for extreme heat wave events used in Trimmel et al. (2016a) are available for download. Other parts of the data set may be included later after they have been published.

\section{General information}

dataset entry ID:

name of the dataset:

full name of the dataset:

dataset short name:

type of dataset:
FWM 8

Abiotic and biotic data of the rivers Pinka and Lafnitz 2012 - 2014

BIO_CLIC

species (taxonomic group) per site database including environmental 


\author{
information \\ data type: \\ point data/observation data \\ science keywords according to GCMD: \\ topic: \\ Atmosphere, Biosphere, Biological Classification, Climate Indicators \\ ISO topic category according to ISO 19115:
}

Biota, Climatology/Meteorology/Atmosphere, Environment, Inland Waters

\title{
Technical and administrative specifications
}

data format:
others/details:
operating system:
others/details:
data language:
current access level:
web address:
others/details:
currently available through GBIF:
exchange planned:
data in data repository:
specify repository:

others/specify

different data formats: csv, txt, Access, Excel

all operating systems

some data is only available for Windows

English

web (public)

http://data.freshwaterbiodiversity.eu/data/FWM_8-Pinka_Lafnitz/

data are deposited in the repository of the Freshwater Biodiversity Data Portal

no

no

yes

Initially only stream water observations, predictions of the river Pinka and corresponding input data for extreme heat wave events used in Trimmel et al. (2016a) are available for download. Other parts of the data set may be included after they have been published.

\section{Do you plan to publish the data on the Freshwater Biodiversity Data Portal:}

\section{update level: \\ others/details: \\ documentation: \\ type: \\ others/details: \\ language: \\ specify:}

\section{contact details:}

metadata contact person:

first, last name:

phone:

email:

institution:

address:

postal code, city:

province, state:

country

web address:

technical contact person:

first, last name:

phone:

email: already published through the Freshwater Biodiversity Data Portal

completed, others/specify

some data are not analyzed yet

scientific paper, others/specify

http://bioclic.boku.ac.at

English

final report

Trimmel Heidelinde

+4314765481425

heidelinde.trimmel@boku.ac.at

Institute of Meteorology, University of Natural Resources and Life Sciences

Gregor-Mendel-Strasse 33

1180 Vienna

Vienna

Austria

https://www.wau.boku.ac.at/en/met/

Martin Seebacher

+4314765481220

martin.seebacher@boku.ac.at 
institution:

address:

postal code, city:

country:

web address:

scientific contact person:

first, last name:

phone:

email:

comments:
Institute of Hydrobiology and Aquatic Ecosystem Management

Gregor-Mendel-Strasse 33

1180 Vienna

Austria

http://www.wau.boku.ac.at/en/ihg/

Andreas Melcher

+4314765481223

andreas.melcher@boku.ac.at

other related websites:

http://bioclic.boku.ac.at/

http://www.wau.boku.ac.at/met/forschungsthemen/atmosphaerische-strahlung /forschungsbereich-strahlung-energiebilanz-und-bodengebundene-fernerkundu $\mathrm{ng} /$ forschungsschwerpunkte/strahlungstransport-und-energiebilanz-in-gewaesse rn

\section{Intellectual property rights and citation}

\section{dataset publisher: \\ dataset creator (data compiler): \\ contact name: \\ contact email: \\ contact institution:}

Heidelinde Trimmel

Heidelinde Trimmel

heidelinde.trimmel@boku.ac.at

Institute of Meteorology, University of Natural Resources and Life Sciences

data contributors to/owners of this dataset:

number:

multiple

6

data contributor/owner 1:

contact name:

Gerda Kalny

contact email:

gerda.kalny@boku.ac.at

contact institute:

Institute of Soil Bioengineering and Landscape Construction, Univ. of Nat. Res.

criteria for using this part of the dataset:

The dataset needs to be requested from dataset creator with specific conditions of use.

comments:

river morphology, field study

riparian vegetation, field study

data contributor/owner 2:

contact name:

Philipp Weihs

contact email:

philipp.weihs@boku.ac.at

contact institute:

Institute of Meteorology, University of Natural Resources and Life Sciences

criteria for using this part of the dataset:

The dataset needs to be requested from dataset creator with specific conditions of use.

comments:

stream water temperature, measurements

near stream microclimate, measurements

\section{data contributor/owner 3:}

contact name:

contact email:

Heidelinde Trimmel

contact institute:

heidelinde.trimmel@boku.ac.at

Institute of Meteorology, University of Natural Resources and Life Sciences

criteria for using this part of the dataset:

The dataset is publicly available (data portal, data archive) and can be used 
without restrictions, but dataset creator/data contributors must be informed

comments: prior to publication. Data must be acknowledged and cited correctly.

\section{data contributor/owner 4:}

contact name:

contact email:

contact institute:
Andreas Melcher

andreas.melcher@boku.ac.at

Institute of Hydrobiology and Aquatic Ecosystem Management, Univ. of Nat. Res.

criteria for using this part of the dataset:

The dataset needs to be requested from dataset creator with specific conditions of use.

comments:

\section{data contributor/owner 5:}

contact name:

contact email:

contact institute:

fish species and assemblages, sampling

Florian Dossi

florian.dossi@boku.ac.at

Institute of Hydrobiology and Aquatic Ecosystem Management, Univ. of Nat. Res.

criteria for using this part of the dataset:

The dataset needs to be requested from dataset creator with specific conditions of use.

comments:

\section{data contributor/owner 6:}

contact name:

contact email:

contact institute:

benthic invertebrate abundance and diversity, sampling

criteria for using this part of the dataset:

Herbert Formayer

herbert.formayer@boku.ac.at

Institute of Meteorology, University of Natural Ressources and Life Sciences

The dataset needs to be requested from dataset creator with specific conditions of use.

comments:

near stream microclimate, numerical predictions

\section{citation of this dataset:}

author(s):

Kalny, G., Dossi, F., Formayer, H., Graf, W., Rauch, H.P, Trimmel, H., Weihs, P., Melcher, A.

title and journal (name, number, pages):

year:

Abiotic and biotic data of the rivers Pinka and Lafnitz 2012 - 2014

doi:

2016

citation of the metadata:

author(s):

https://doi.org/10.13148/BFFWM8

title and journal (name, number, pages):

Trimmel H., Kalny G., Dossi F., Formayer H., Graf W., Leitner P., Leidinger D., Nadeem I., Rauch H. P., Weihs P. \& Melcher A.

Abiotic and biotic data of the rivers Pinka and Lafnitz 2012 - 2014. Freshwater

Metadata Journal 22: 1-12

year:

2017

doi:

https://doi.org/10.15504/fmj.2017.22

\section{dataset related references:}

reference 1:

author(s):

title:

Trimmel, H., Gangneux, C., Kalny, G., Weihs, P.

Application of the model "Heat Source" to assess the influence of meteorological components on stream temperature and simulation accuracy under heat wave conditions. Meteorologische Zeitschrift, 25/4, 389-406 
year:

doi:

reference 2:

author(s):

title:

year:

doi:

reference 3:

author(s):

title:

year:

doi:

reference 4:

author(s):

title:

year:
$2016 b$

https://doi.org/10.1127/metz/2016/0695

Melcher, A., Kalny, G., Dossi, F., Formayer, H., Graf, W., Pletterbauer. F., Schaufler, K., Trimmel, H., Weihs, P., Rauch, H.P.

Der Einfluss der Ufervegetation auf die Wassertemperatur unter gewässertypspezifischer Berücksichtigung von Fischen und benthischen Evertebraten am Beispiel von Lafnitz und Pinka. Journal Österreichische Wasser- und Abfallwirtschaft, 68(7), 308-323

2016

https://doi.org/10.1007/s00506-016-0321-8

Trimmel, H., Weihs, P., Leidinger, D., Formayer, H., Kalny, G.

Can riparian vegetation shade mitigate the expected rise in stream temperature during heat waves in a pre-alpine river? Hydrology and Earth System Sciences, Discussion

2016a

https://doi.org/10.5194/hess-2016-230

Holzapfel, G., Rauch, H.P.

Der Einfluss der Ufervegetation auf die Wassertemperatur der Lafnitz und Pinka. Mitteilungsblatt für die Mitglieder des Vereins für Ingenieurbiologie, Ingenieurbiologie: Neue Entwicklungen an Fließgewässern, Hängen und Böschungen, 1/2015, 4-10

2015

\section{General data specifications}

regional coverage of the dataset: spatial extent of the dataset:

catchment

continents:

Europe

spatial extent (bounding coordinates):

southernmost latitude $\left[^{\circ}\right]$ :

46.9766

northernmost latitude $\left[^{\circ}\right]$ :

47.5153

westernmost longitude $\left[{ }^{\circ}\right]$ :

15.8115

easternmost longitude $\left[{ }^{\circ}\right]$ :

16.4939

minimum altitude:

240 metres

maximum altitude:

1480 metres

countries:

Europe: Austria

world climatic regions according to Köppen:

Group D: continental/microthermal climate

freshwater ecoregions of the world (FEOW) according to WWF:

Europe: Upper Danube

European ecoregions according to Illies (WFD):

ecosystem type: covered timeframe:
Alps (ER4), Hungarian Lowlands (ER11)

rivers

$2012-2014$ 


\section{Site specifications}

coordinate system/grid data: datum (e.g. WGS84):

site coding:

site coding available:

number of digits:

example:

number of sites:

exact number of sites:

comments: projected, others others: MGI_Austria_GK_M34, Transverse Mercator

Bessel_1841

yes, alphanumerical

12

L_ROHR_26,08

$<100$

64

There are two different site codings used:

(1) The water temperature simulation dataset uses the side coding distance from mouth (km 89-38, each 500m). Here only the river Pinka is included. (2) In the additional datasets of each research group the data is sorted according to an alphanumerical code denoting the river distance from source of the field survey sample points.

\section{Climate and environmental data}

\section{climate related data:}

spatial resolution of the data (if not catchment/site related):

others:

others/specify

available parameters per catchment:

at reference station

hourly air humidity, air temperature, wind, global radiation

data source: own measurements / regional climate scenarios

comments:

The following data are included in the downloadable data set: (1) hourly air humidity, air temperature, wind, global radiation was recorded at our reference station at an unobstructed site at Pinka DFS 39 (Trimmel et al. 2016a+b); (2) INCA data (Haiden et al. 2011) were compared and adjusted to fit the local site; (3) for future scenarios data was extracted from regional climate scenarios (Radu et al. 2008). The full methodology is described in Trimmel et al. 2016a.

Additional continuous and campaign meteorological measurements were made to characterize the near stream microclimate and energy balance at the river surface, which are not included in the downloadable data (air temperature/air humidity/global radiation/PAR within the riparian vegetation buffer, radiation balance at the river).

Haiden, T., Kann, A., Wittmann, C., Pistotnik, G., Bica, B., and Gruber, C., 2011. The Integrated Nowcasting through Comprehensive Analysis (INCA) System and Its Validation over the Eastern Alpine Region, Weather Forecast., 26, 166-183, doi:10.1175/2010WAF2222451.1

Radu, R., Déqué, M., Somot, S., 2008. Spectral nudging in a spectral regional climate model, Tellus A Dynamic Meteorology and Oceanography, 60 Issue: 5 Pages: 898-910.

\section{environmental data:}

available parameters per catchment:

catchment land cover/land use data source: own measurements/field study 
available parameters per site:

\section{physico-chemical data: \\ stressors influencing the sites:}

reference sites available: river morphology, riparian vegetation, water temperature measurements data source: own measurements/field study/simulations

river length

data source: field study/ part of simulation input

distance to source

data source: field study

distance to mouth

data source: field study/ part of simulation input

stream order (according to Strahler)

data source: field study

slope

data source: part of simulation input, calculated with TTools

altitude

data source: part of simulation input, calculated with TTools

hydrological regime/flow regime

data source: own measurements/field study

discharge

data source: part of simulation results

current velocity

data source: part of simulation results

maximum depth

data source: part of simulation results

mean depth

data source: part of simulation results

substrate composition

data source: part of simulation results

water temperature

yes

\begin{tabular}{|l|l|l|l|l|}
\hline stressor & $\begin{array}{l}\text { restored sites } \\
\text { available }\end{array}$ & $\begin{array}{l}\text { data before/after } \\
\text { restoration } \\
\text { available }\end{array}$ & $\begin{array}{l}\text { stressor gradient } \\
\text { available }\end{array}$ & comments \\
\hline thermal stress & yes & no & yes & \\
\hline
\end{tabular}

\section{Biological data}

biological data origin:

organism group addressed: from sampling,

BIO_CLIC, Austria

fish, macro-invertebrates (Mollusca, Ephemeroptera, Odonata, Plecoptera, Coleoptera, Trichoptera, Chironomidae), angiosperms (riparian vegetation), invasive species

\section{Sample specifications/sample resolution}

fish:

sample information: 
covered timeframe:

historical data:

palaeo data:

season:

temporal resolution/frequency of sampling:

time series data:

comments:

\section{taxonomic resolution:}

level:

percentage of species level data: 100

\section{taxonomic coding:}

taxalist according to:

reference(s):

\section{sample specifications:}

replicate samples:

number of samples:

specification of method(s) used for sampling and sorting:

\section{BMFLUW 2010}

BMLFUW, Federal Ministry of Agriculture, Forestry, Environment and Water Management (Publisher). 2010: Leitfaden zur Erhebung der biologischen Qualitätselemente Teil A1 - Fische. Vienna

yes

626

Allover, several transects at a total of 17 stretches (626 sampling points in the Lafnitz and 271 in the Pinka) were recorded to characterize the abiotic meso habitats. Beside the abiotic characterization of the habitats, point-abundance electric fish samplings $(n=35)$ were performed to record the occurring fish species and their life stages in 2012 and October 2013.

To describe and analyze temporal trends of fish communities datasets were assembled from different sources (IHG DB) and ATFIBASE database (BAW Scharfling). Additionally, fish data from the river Lafnitz was provided by Gerhard Woschitz and Georg Wolfram. Altogether, 52 fish sampling events from external sources were included in the dataset for this study, covering the period from 1991 to 2013 (Guldenschuh 2014).

reference(s): Guldenschuh M., 2014. Longitudinal zonation of habitat parameters and fish species assemblages in the Austrian lowland rivers Lafnitz and Pinka.

Masterthesis at the University of Natural Resources and Life Sciences, Vienna. sample type (e.g. habitat specific samples, composite samples etc.):

Habitat sampling 2012 and 2013, additional historic quantitative and qualitative data from 1991 on.

specific sample location (e.g. littoral, profundal, transect, shoreline, hyporheic zone, etc.):

All river, from upstream down to the Hungarian border.

\section{macro-invertebrates:}

sample information:

covered timeframe:

historical data:

$2012-2014$

palaeo data:

no

season:

no

spring, summer, autumn

temporal resolution/frequency of sampling:

4 times in three years

time series data:

no

comments:
Samples were taken in: May 2012; August 2012; October 2012; March 2014. 


\section{taxonomic resolution:}

level:

percentage of species level data: 70

comments:

Identification was mainly based on the Screening-Taxa List according to Ofenböck et al. (2010). However, in many cases Ephemeroptera, Plecoptera and Trichoptera taxa could be identified to a lower level, whereas Diptera taxa were mainly identified to family level. The taxonomic composition of each site was quantified using the Regional Zonation Index (RZI) calculated by the software Ecoprof 4.0 (Moog et al., 2013).

\section{taxonomic coding:}

taxalist according to:

Ofenböck et al. (2010)

reference(s):

Ofenböck, T., Moog, O., Hartmann, A., \& Stubauer, I., 2010. Leitfaden zur Erhebung der biologischen Qualitätselemente Teil A2-Makrozoobenthos. Bundesministerium für Land- und Forstwirtschaft, Umwelt- und Wasserwirtschaft, S. 1-103.

\section{sample specifications:}

replicate samples:

no

number of samples:

406

specification of method(s) used for sampling and sorting:

- In May and August 2012 lithal substrates were sampled according to the Multi-Habitat-Sampling approach (AQEM-Consortium, 2002) (19 samples Lafnitz and 16 samples Pinka). Twenty pooled samples were taken at each investigation site, whereby each sample represents a 5\% share of available habitats in the river section.

- In October 2012 and March 2014, single-habitat-samples per transects were taken (290 samples Lafnitz). At least 20 sampling units were taken at each site. Choriotope type as well as flow velocity (bottom; near and at $40 \%$ of water depth) was documented for each sample.

- Habitat structures directly linked to the riparian vegetation such as large wood (LW) were sampled separately at alles dates if present $(58 \mathrm{LW}$ samples Lafnitz and $6 \mathrm{LW}$ samples Pinka). Length, width and volume of each large wood piece were measured to calculate macro-invertebrate densities $\left(\mathrm{Ind} / \mathrm{m}^{2}\right)$ and biomass per square meter.

- In addition, adults were collected with light traps and sweeping net to support the identification of Ephemeroptera, Plecoptera and Trichoptera species (11 sampling dates Lafnitz and 6 sampling dates Pinka).

- The screening taxa list according to Ofenböck et al. (2010) was used as reference species list.

reference(s):

- AQEM consortium, 2002. Manual for the application of the AQEM system. A comprehensive method to assess European streams using benthic macroinvertebrates, developed for the purpose of the Water Framework Directive. Version 1.0, February 2002.

- Moog, O., Hartmann, A., Schmidt-Kloiber, A., Vogl, R., \& Koller-Kreimel, V., 2013. ECOPROF Vers. 4.0, www.ecoprof.at.

- Ofenböck, T., Moog, O., Hartmann, A., \& Stubauer, I., 2010. Leitfaden zur Erhebung der biologischen Qualitätselemente Teil A2-Makrozoobenthos. Bundesministerium für Land- und Forstwirtschaft, Umwelt- und Wasserwirtschaft, S. 1-103.

sample type (e.g. habitat specific samples, composite samples etc.):

- MHS sampling according to AQEM (2002) in May and August of 2012

- Single habitat sampling in October 2012 and March 2014 
angiosperms:

sample information:

covered timeframe:

historical data:

season:

time series data:

comments:

taxonomic resolution:

level:

percentage of species level data: 75

comments:

taxonomic coding:

taxalist according to:

reference(s):

\section{sample specifications:}

replicate samples:

number of samples:

specification of method(s) used for sampling and sorting:

Definition of areas of same vegetation composition by aerial photographs.

Overall height, density and dominating species were recorded in field. Reference species lists were used from Cejka et al. (2005)

reference(s):

Cejka, A., Dvorak., M., Fortmann, I., Knogler, E., Korner, I., Schlögl, G.,

Wendelin, B., Wolfram, G., Zechmeister T.C., Das Lafnitztal: Flusslandschaft im Herzen Europas, Federal Environment Agency - Austria, Vienna, 2005. specific sample location (e.g. littoral, profundal, transect, shoreline, hyporheic zone, etc.):

Riparian vegetation in a $50 \mathrm{~m}$ buffer orographically left and right of the river bank from source to the Austrian border.

\section{invasive species:}

sample information:

covered timeframe:

historical data:

season:

time series data:

taxonomic resolution:

taxonomic coding:

sample specifications:

comments:
$2013-2013$

no

summer

no
Invasive species are included in the angiosperm data set; rough estimation.

\section{Other specifications}

GIS layers, shape files related to the dataset:

others/details:

\section{others/specify}

measurement points and sampling habitats 


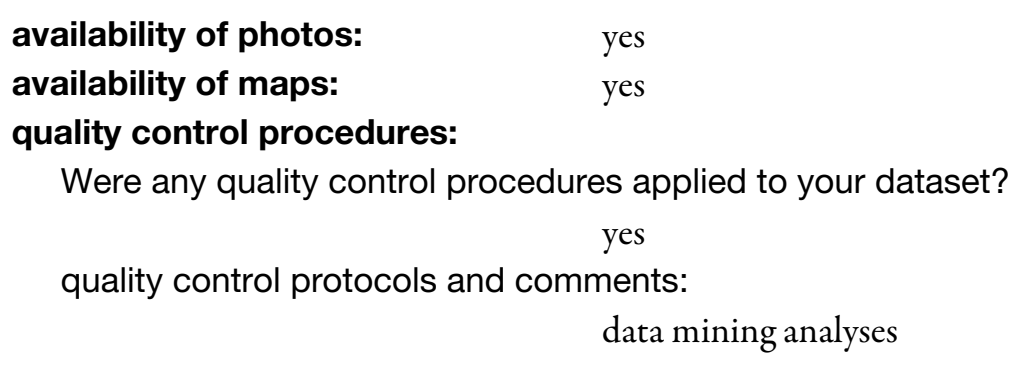

\section{Acknowledgements}

This research was part of the project BIO_CLIC and LOWFLOW+ both funded within the Austrian Climate Research Programme (ACRP) by the Klima und Energiefond. The regional climate model data sets used to produce the climate episodes were developed in the ENSEMBLES project supported by the European Commission. The INCA data set was created by the national weather service (ZAMG). Hydrological data and the digital elevation model were provided by hydrographic services, which are part of the Federal Ministry of Agriculture, Forestry, Environment and Water Management and the federal state governmental geoinformation service authorities of Styria and Burgenland. Fish data were provided by Gerhard Woschitz, Georg Wolfram, BAW Scharfling, and federal states Styria and Burgenland. Special thanks are given to the Oregon Department of Environmental Quality, who maintain the model Heat Source and opened the source code for scientific use.

\section{References}

AQEM consortium, 2002. Manual for the application of the AQEM system. A comprehensive method to assess European streams using benthic macroinvertebrates, developed for the purpose of the Water Framework Directive.

BMLFUW, Federal Ministry of Agriculture, Forestry, Environment and Water Management, 2010. Leitfaden zur Erhebung der biologischen Qualitätselemente Teil A1 - Fische. Vienna

Boyd, M., Kasper, B., 2003. Analytical methods for dynamic open channel heat and mass transfer: Methodology for heat source model Version 7.0.

Cejka, A., Dvorak., M., Fortmann, I., Knogler, E., Korner, I., Schlögl, G., Wendelin, B., Wolfram, G., Zechmeister T.C., 2005. Das Lafnitztal: Flusslandschaft im Herzen Europas, Federal Environment Agency - Austria, Vienna

Guldenschuh, M., 2014. Longitudinal zonation of habitat parameters and fish species assemblages in the Austrian lowland rivers Lafnitz and Pinka. master thesis at the University of Natural Resources and Life Sciences, Vienna.

Haiden, T., Kann, A., Wittmann, C., Pistotnik, G., Bica, B., Gruber, C., 2011. The Integrated Nowcasting through Comprehensive Analysis (INCA) System and Its Validation over the Eastern Alpine Region. Weather Forecasting, 26, 166-183. https://doi.org/10.1175/2010WAF2222451.1

Holzapfel, G., Rauch, H.P., 2015. Der Einfluss der Ufervegetation auf die Wassertemperatur der Lafnitz und Pinka. Mitteilungsblatt für die Mitglieder des Vereins für Ingenieurbiologie, Ingenieurbiologie: Neue Entwicklungen an Fließgewässern, Hängen und Böschungen, 1/2015, 4-10.

Melcher A., G. Kalny, F. Dossi, H. Formayer, W. Graf, F. Pletterbauer, K. Schaufler, H. Trimmel, P. Weihs, Rauch, H.P., 2016. Der Einfluss der Ufervegetation auf die Wassertemperatur unter gewässertypspezifischer Berücksichtigung von Fischen und benthischen Evertebraten am Beispiel von Lafnitz und Pinka. Journal Österreichische Wasser- und Abfallwirtschaft, 68(7), 308-323. https://doi.org/10.1007/s00506-016-0321-8

Moog, O., Hartmann, A., Schmidt-Kloiber, A., Vogl, R., Koller-Kreimel, V., 2013. ECOPROF Vers. 4.0 Software zur Bewertung des ökologischen Zustandes von Fliessgewässern nach WRRL.

Ofenböck, T., Moog, O., Hartmann, A., Stubauer, I. , 2010. Leitfaden zur Erhebung der biologischen Qualitätselemente Teil A2-Makrozoobenthos. Bundesministerium für Land- und Forstwirtschaft, Umwelt- und Wasserwirtschaft. 
Radu, R., Déqué, M., Somot, S., 2008. Spectral nudging in a spectral regional climate model, Tellus A Dynamic Meteorology and Oceanography, 60 Issue: 5: 898-910.

Trimmel, H., Gangneux, C., Kalny, G., Weihs, P., 2016b. Application of the model "Heat Source" to assess the influence of meteorological components on stream temperature and simulation accuracy under heat wave conditions.

Meteorologisce Zeitschrift, 25/4, 389-406. https://doi.org/10.1127/metz/2016/0695

Trimmel, H., Weihs, P., Leidinger, D., Formayer, H., Kalny, G., 2016a. Can riparian vegetation shade mitigate the expected rise in stream temperature during heat waves in a pre-alpine river? Hydrology and Earth System Science, Discussion. https://doi.org/10.5194/hess-2016-230 